\title{
A possible worlds semantics for Cuzco Quechua evidentials.
}

Link to publication record in Manchester Research Explorer

\section{Citation for published version (APA):}

Faller, M., Li, N., \& Lutz, D. (Ed.) (2011). A possible worlds semantics for Cuzco Quechua evidentials.. 660-683. http://elanguage.net/journals/index.php/salt/article/view/20.660

\section{Citing this paper}

Please note that where the full-text provided on Manchester Research Explorer is the Author Accepted Manuscript or Proof version this may differ from the final Published version. If citing, it is advised that you check and use the publisher's definitive version.

\section{General rights}

Copyright and moral rights for the publications made accessible in the Research Explorer are retained by the authors and/or other copyright owners and it is a condition of accessing publications that users recognise and abide by the legal requirements associated with these rights.

\section{Takedown policy}

If you believe that this document breaches copyright please refer to the University of Manchester's Takedown Procedures [http://man.ac.uk/04Y6Bo] or contact uml.scholarlycommunications@manchester.ac.uk providing relevant details, so we can investigate your claim.

\section{OPEN ACCESS}




\title{
A possible worlds semantics for Cuzco Quechua evidentials*
}

\author{
Martina Faller \\ The University of Manchester
}

\begin{abstract}
This paper proposes an analysis of Cuzco Quechua evidentials within the possible worlds framework developed by Kratzer (1981, 1987, 2010), and explores how the tools provided by this framework can be used to best capture their evidential and epistemic modal aspects. In particular, it will be discussed how differences between evidentials can be accounted for by different restrictions on the modal base and ordering source.
\end{abstract}

Keywords: evidentiality, epistemic modality, possible worlds semantics

\section{Introduction}

In the formal literature on evidentiality it is often assumed that evidentials can be analyzed as epistemic modals with an evidential presupposition within Kratzer's (1981; 1987) framework of possible worlds semantics, see, for example, the seminal work by Izvorski (1997) and subsequent work such as Ehrich 2001, Matthewson, Davis \& Rullmann 2007 and Rullmann, Matthewson, \& Davis 2008. This paper explores how the tools provided by this framework can be used to best capture the evidential and epistemic modal aspects of the evidentials of Cuzco Quechua (CQ). In particular, it will be discussed how differences between evidentials can be accounted for by different restrictions on the modal base and ordering source. The discussion contributes to the ongoing debate about whether evidentials can be subsumed under the category of epistemic modals.

The remainder of this introduction provides background on evidentiality and epistemic modality as well as Cuzco Quechua. In section 2, the use and meaning of CQ evidentials will be described and illustrated. Section 3 summarizes the main relevant points of Kratzer's $(1981$; 1987) account of (epistemic) modality, and its application to evidentials in the literature. Section 4 builds on these previous accounts and proposes modifications to capture the differences between the CQ evidentials. The main proposal is that inferential evidentials rely on an ordering source, whereas non-inferential evidentials constrain the modal base.

* I would like to thank the audiences at SALT XX, Vancouver, and SPINFest 2, York, for their insightful comments and questions on previous versions of this paper. 
Cuzco Quechua evidentials

\subsection{Evidentiality and epistemic modality}

Evidentiality and epistemic modality are closely related yet distinct conceptual categories (Aikhenvald \& Dixon 2003; Faller 2002; de Haan 1999). Epistemic modality marks the speaker's degree of certainty or the necessity/possibility of the truth of the proposition expressed by $p$. For example, the CQ enclitic -puni in (1a) expresses that the speaker is certain to a high degree that it rained, while the English modal might in (1b) expresses that the speaker considers this a possibility. ${ }^{1}$
a. Para-mu-sha-rqa-n=puni.
(Cuzco Quechua) rain-CISL-PROG-PST-3=CERT

'It was certainly raining.'

b. It might have been raining.

Evidentiality, in contrast, indicates the speaker's type of source of information for $p$ (in assertions). For example, the CQ enclitic $=m i$ in (2a) indicates that the speaker saw that it was raining, and the German modal verb sollen in (2b) that the speaker was told that it is raining by someone else.

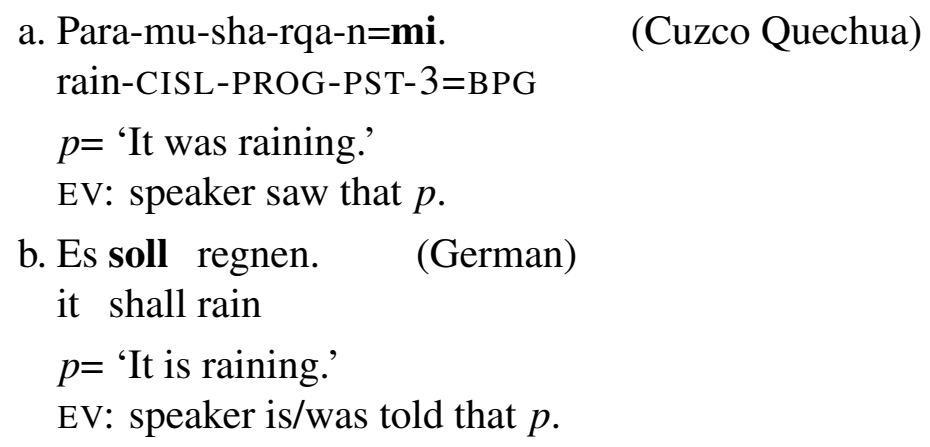

(Cuzco Quechua)

Cross-linguistically, the types of source of information in Table 1 occur.

While epistemic modality and evidentiality are clearly distinct conceptually, they are also closely related as the speaker's evaluation of the truth of a proposition will often be influenced by the way they have learnt about that proposition. Moreover, it is not always possible to establish two distinct categories empirically in a given language, as can be demonstrated with the English modal verb must. Consider (3).

1 Unless otherwise indicated, the Cuzco Quechua examples were elicited in interview sessions with native speakers by the author. Abbreviations: 1,2,3: first, second, third person, ABL: ablative, ACC: accusative, ADD: additive, BPG: best possible grounds, CAUS: causative, CISL: cislocative, COM: comitative, COND: conditional, CONJ: conjectural, CONTR: contrastive, DIM: diminutive, DISC: discontinuous, EV: evidential value, EXCL: exclusive, FUT: future, GEN: genitive, IMPR: impressive, INCH: inchoative, INCL: inclusive, LOC: locative, NEG: negative, NX.PST: non-experienced past, PEI: perceived evidence inferential, PL: plural, , POSS: possessive, PROG: progressive, PRT: participle, PST: past, REFL: reflexive, REP: reportative, TOP: topic. Variables: $p$ : proposition, $s$ : speaker. 


\begin{tabular}{ccc} 
Direct & \multicolumn{2}{c}{ Indirect } \\
Attested & Inference & Reported \\
Visual & Results & Secondhand \\
Auditory & Reasoning & Thirdhand \\
Other Sensory & & Folklore
\end{tabular}

Table 1 Types of source of information (Willett 1988)

(3) a. Context 1: Speaker sees people coming in with wet raingear It must be raining.

b. Context 2: Speaker looks out the window and sees that it's raining. \#It must be raining.

(von Fintel \& Gillies 2010)

Epistemic must expresses the speaker's evaluation of $p$ as necessarily true and it is therefore an epistemic modal. But as (3b) demonstrates, it is infelicitous when the speaker has direct evidence for $p$, and it can therefore also be classified as an indirect evidential. More precisely, must has been argued to "signal that the prejacent was reached through an inference rather than on the basis of direct observation or trustworthy reports" (von Fintel \& Gillies 2010).

From a theoretical perspective, if both evidentials and epistemic modals can be analyzed in essentially the same way, then there is arguably no reason to distinguish two categories (Matthewson 2010). The question then is which differences in their semantics warrant the recognition of two separate categories, and which ones do not. This paper concludes that, at a coarse-grained level of analysis, evidentials and epistemic modals can both be treated as quantifiers over possible worlds in a modal base. However, at a finer-grained level, important distinctions appear which warrant keeping the two categories distinct.

\subsection{Cuzco Quechua}

The term Quechua refers to a family of languages spoken in the Andes region. The variety studied here is Cuzco Quechua (CQ), spoken in the Department of Cuzco, Peru. The basic word order of CQ is SOV but is flexible due to case marking. There is widespread pro-drop of both subjects and objects. It is an agglutinative language and possesses a large number of enclitics as well as derivational and inflectional suffixes. Suffixes and enclitics are arranged in a template after the root as shown in (4a), with a number of slots within each category, as illustrated in (4b). 
Cuzco Quechua evidentials
a. ROOT-derivational-inflectional=enclitics
b. Mana $=$ s tayta-y-ta $=q a \quad$ rima-ri-chi-sqa-ku=pas $=$ chu not=REP father-1-ACC=TOP speak-INCH-CAUS-NX.PST-PL=ADD $=$ PL

'Reportedly, they didn't let my father talk'

(Cusihuaman 2001: 84)

\section{The Cuzco Quechua evidentials}

Evidentiality in CQ is mainly expressed with a set of enclitics, paradigmatically illustrated in (5). ${ }^{2}$

(5) Para-mu-sha-n=mi/=si/=chá/=chu-sina. rain-CISL-PROG-3=BPG/REP/CONJ/RES

$p=$ 'It is raining.'

(i) Direct $=m i /=n: s$ sees that it is raining.

(ii) Reportative, $=s i /=s$ : $s$ was told that it is raining.

(iii) Conjectural, =chá: $s$ conjectures that it is raining.

(iv) Partial evidence/inference from results, $=$ chu-sina/=(chu)-suna: $s$ infers from available evidence that it is raining.

The evidential enclitics are a subset of the focus enclitics, and they cannot co-occur with each other in a clause.

\subsection{Best possible grounds/Direct $=m i$}

The enclitic $=m i$ indicates that the speaker has direct evidence in cases where the described event is directly observable or otherwise directly accessible, as, for example, in (6).

(6) Subrina-y-wan=mi tiya-sha-n.

niece-1-COM=BPG live-PROG-3

'He is living with my niece.'

EV: $s$ has seen that he is living with her niece.

(conversation)

If the event described is not directly observable such as someone else's future plans or emotions, =mi is felicitous when the speaker has the "the next best thing" to direct evidence, what Faller (2002) calls best possible grounds. For the examples in (7), the best possible grounds would be a report by Inés herself; reports by others or assumptions by the speaker do not license the use of $=m i$ for such events.

2 CQ moreover has two past tense markers, one of which indicates that the speaker did not witness the described event. This past tense is analyzed in Faller 2004. 
a. Paqarin Inés Qusuq-ta=n ri-nqa. tomorrow Inés Cuzco-ACC-BPG go-3.FUT

'Inés will go to Cuzco tomorrow.'

EV: Inés told $s$ that she will go to Cuzco tomorrow.

(elicited)

b. Inés llaki-ku-n=mi.

Inés be.sad-REFL-3=BPG

'Inés is sad.'

EV: Inés told $s$ that she is sad.

(elicited)

In this paper, I will only be concerned with examples involving direct evidence.

\subsection{Reportative $=s i$}

The enclitic $=s i$ is used when the speaker has acquired the proposition expressed $p$ via reports from others, and is found in all types of genres, including conversation, folktales and news reporting, (8).

$$
\begin{aligned}
& \text { a. Congresista-manta }=\mathbf{s} \text { haykuy-ta muna-n. } \\
& \text { congressman-ABL }=\text { REP enter- } A C C \text { want }-3
\end{aligned}
$$

'He wants to be a Congressman.'

(conversation)

b. Chaya-n=si ukuku uña=qa. Punku-ta=s taka-ku-n, arrive-3=REP bear baby. animal=TOP door-ACC=REP knock-REFL-3 ch'in.

silent

'The son of the bear arrived. He knocked on a door, silence.'

(Itier 1999: 44)

c. Wakin=si maqa-mu-n-ku hayt'a-mu-n-ku. some $=$ REP hit-CIS-3-PL kick-CIS-3-PL

'Some hit and kicked (him).'

(news report)

\subsection{Inferentials =chá and $=c h u-\sin a$}

CQ has two Inferential enclitics, which correspond to a cross-linguistically common distinction between Inference from Reasoning and Inference from Results (Willett 1988). The Conjectural = chá can be used for inferences from a set of premises, (9), as well as for speculation (see examples in section 4.1). 
Cuzco Quechua evidentials

(9) a. Mana=n para $k a n=c h u . ~ K u n a n$ wata=qa mana=chá allin=chu not $=$ BPG rain be $=$ NEG now year $=$ TOP not $=\mathrm{CONJ}$ good $=\mathrm{NEG}$ kuhichu ka-nqa! harvest be-3.FUT

'There is no rain. I guess/suppose/surely, the harvest this year will be bad!'

(Cusihuaman 2001: 233)

b. Context: $s$ knew the person referred to with 'he' in her childhood.

Suqta chunka wata-yuq ka-sha-n=chá.

six ten year-POSS be-PROG-3=CONJ

'He must be sixty years (old).'

(conversation)

The enclitic combination =chu-sina, which I call the Perceived Evidence Inferential (PEI), ${ }^{3}$ is used for inferences based on some kind of observable, partial evidence, often the result of the event described, as in (10). ${ }^{4}$ The difference between =chu-sina and =chá can best be brought out by considering their applicability in different contexts. Consultants agree that $=c h u$-sina is preferred over $=$ chá in a context such as (10a), where the speaker has direct evidence for the premiss, but $=$ chá is preferred in a context where there is more reasoning involved as in (9b).

a. Context: Marya looks very pale.

Unqu-sqa=chu-sina ka-sha-n-man.

sick-PRT =PEI be-PROG-3-COND.

'She appears to be sick.'

3 The Conjectural =chá is regularly included in the set of evidentials in the literature, but $=$ chu-sina is not usually discussed as part of this set. However, as this enclitic can be used for inference from results as well as from perceived evidence more generally, it also qualifies as an evidential. I adopt the spelling of this enclitic in Cusihuaman 2001: 235. Another form encountered in written texts is = chus hina .

4 From the description in Cusihuaman 2001 it appears that =chu-sina has wider applications, extending also to inferences based on reports. Cusihuaman (2001: 235) gives the example in (i), which would seem to make most sense in a context in which the speaker was told that they would go harvest potatoes tomorrow. However, he gives no context, and it is therefore not clear what the basis for the inference actually is.

(i) Paqarin-qa papa-ta-suna aysa-mu-saqku. tomorrow-TOP potato-ACC-PEI harvest-CISL-1.FUT.EXCL

'It seems we'll be harvesting potatoes tomorrow.'

(Cusihuaman 2001: 235) 
Martina Faller

b. Mama-cha-suna haqay-qa hamu-shá-n.

mother-DIM-PEI that-TOP come-PROG-3

'That seems to be our mother who is coming.'

(Cusihuaman 2001: 235)

\section{Previous analyses of evidentials within Kratzer's framework of modality}

Formal semantics accounts of evidentials tend to analyze them as epistemic modals, that is, as quantifiers over possible worlds, with an added evidential condition, often taken to be a presupposition. ${ }^{5}$ The first analysis of this kind was proposed by Izvorski (1997) and has been adopted (with variations) by subsequent work such as Ehrich 2001; Matthewson et al. 2007; Rullmann et al. 2008 and others. My own previous work on CQ evidentials (Faller 2002) has focussed on establishing whether or not they contribute to the proposition expressed and argues that, in this language at least, evidentials are speech act operators, adding a sincerity condition such as: $\operatorname{Direct}(p)$, $\operatorname{Report}(p)$, or Conject $(p)$, which intuitively are to be interpreted as "speaker has directed/reported/conjectural evidence for $p$." The purpose of the current paper is to explore how the truth-conditions of these evidential sincerity conditions can be captured within Kratzer's $(1981 ; 1987)$ framework of modality.

\subsection{Kratzer's doubly-relative account of epistemic modality}

In Kratzer $(1981 ; 1987)$, modal expressions are analyzed relative to two conversational backgrounds, a modal base $f$ and an ordering source $g$, both provided by the context. A conversational background is a function from worlds to sets of propositions (Kratzer 1981, 1987). Depending on what type of modal base is assumed in the context, a modal receives an epistemic, deontic or other modal interpretation. For an epistemic, the modal base provides the set of propositions known by the speaker in $w,(11)$.

(11) Epistemic conversational background $f_{e}$ :

For all $w \in W, f_{e}(w)=\{p \mid s$ knows $p$ in $w\}$

$f_{e}(\mathrm{w})$ projects a set of worlds $\bigcap f_{e}(w)$ that are accessible from $w$, namely those worlds in which all the propositions known in $w$ are true. $\bigcap f_{e}(w)$ is defined in (12).

$$
\bigcap f_{e}(w)=\left\{u \in W \mid \text { for all } p \in f_{e}(w), u \in p\right\}
$$

5 Formal semantic analyses of evidentials which do not analyze them as epistemic modals are Murray 2009 and Schenner 2008. 
Cuzco Quechua evidentials

An ordering source imposes an ordering on the worlds in the modal base. A world $v$ is a better world than $u$ relative to a set of propositions $A$ iff it verifies more propositions in $A$ than $u$.

(13) For all $u, v \in W, u<_{A} v$ iff

$\{p \mid p \in A \wedge u \in p\} \subset\{p \mid p \in A \wedge v \in p\}$

The selection function max defined in (14) selects the set of maximal worlds from a set of worlds $W$ with respect to a set of propositions $A$ (von Fintel \& Iatridou 2005). ${ }^{6}$

$$
\max _{A}(W)=\left\{w \in W \mid \neg \exists v \in W\left[v<_{A} w\right]\right\}
$$

An (epistemic) modal is then analyzed as quantifying over the best worlds in the set of accessible worlds $\bigcap f(w)$, relative to an ordering source $g(w)$. That is, some worlds, possibly including the actual world $w$, may be disregarded when drawing a conclusion. The semantics for must can be given as (15). ${ }^{7}$

$$
\llbracket \operatorname{must}(p) \rrbracket^{w, c, f, g}=1 \text { iff for all } w^{\prime} \in \max _{g(w)}(\bigcap f(w)), \llbracket p \rrbracket^{w^{\prime}, c}=1 .
$$

The ordering source $g(w)$ can, for example, be a set of assumptions about what the world is typically like. To make things more concrete consider example (16).

a. Context: a murder investigation in a Bavarian village. The investigator knows the facts in (16b) and makes the assumptions in (16c).

b. $f_{e}(w)=\{$ Only Jakl and Michl have a motive, Jakl has an alibi, ... $\}$

c. $g(w)=\{$ Murderers have a motive, people with alibis cannot commit a murder, ... $\}$

With these background assumptions, she can justifiably conclude (17).

Michl must be the murderer.

By using must to state her conclusion, the speaker signals that certain worlds might have been excluded from consideration, and thereby leaves open the possibility that the actual world might turn out to be one in which someone other than Michl

6 For the sake of a simpler definition of the selection function, I follow Izvorski (1997), von Fintel \& Iatridou (2005), and others, in making the Limit Assumption, according to which best worlds can always be determined. See Kratzer 2010 for arguments for not making this assumption.

7 I adopt Portner's (2009: 52) way of representing the truth conditions of modals. As is customary, I assume that a linguistic expression is evaluated relative to a world $w$ and a context $c$. For some modals, the modal base $f$ and ordering source $g$ are also contextual parameters. For example, must will receive an epistemic interpretation if $f$ is set to an epistemic modal base. 
is the murderer. That is, with this semantics, must $p$ does not entail $p$, thereby capturing the intuition that must $p$ is weaker, not stronger, than plain $p .{ }^{8}$

If the investigator had less firm grounds to conclude that Michl is the murderer, she could instead conclude that Michl may be the murderer. In contrast to must, may only requires there to be at least one world in the set of maximal worlds in which Michl is the murderer, that is, its semantics is as in (18).

$$
\llbracket \operatorname{may}(p) \rrbracket^{w, c, f, g}=1 \text { iff for some } w^{\prime} \in \max _{g(w)}(\bigcap f(w)), \llbracket p \rrbracket^{w^{\prime}, c}=1 .
$$

In sum, a speaker using an epistemic modal claims that $p$ necessarily or possibly follows from a set of facts and a set of (normalcy) assumptions.

\subsection{Evidentials as epistemic modals}

Previous accounts of evidentials which adopt this framework take evidentials to be just like epistemic modals but with an added evidential presupposition. The seminal work in this area is Izvorski's (1997), who analyzes the "perfect of evidentiality" (PE) in a number of unrelated languages. The PE is a general indirect evidential and can be used for inferences as well as reports. Izvorski (1997) proposes that the PE asserts necessarily $p$ in view of the speaker's knowledge state, and presupposes that the speaker has indirect evidence for $p$. She defines the modal base $f$ and ordering source $g$ for the PE as in (19).

$$
\begin{aligned}
& \text { a. } f(w)=\{p: s \text { considers } p \text { indirect evidence in } w\} \\
& \text { b. } g(w)=\{p: s \text { believes } p \text { with respect to the indirect evidence in } w\}
\end{aligned}
$$

A similar semantics is given by Rullmann et al. (2008) for two St'át'imcets inferentials, which are very similar to the two CQ inferentials, and a reportative evidential. These evidentials share the assertion in (20d), ${ }^{9}$ that is, they are universal quantifiers over an (epistemic) modal base. They differ in what they presuppose about the accessible worlds, as shown in (20a-20c).

\section{a. General inferential} $\llbracket \mathrm{k}^{\prime} \mathrm{a} \rrbracket^{c, w}$ is only defined if $c$ provides an epistemic modal base B s.t. for all worlds $w^{\prime}, w^{\prime} \in B(w)$ iff the inferential evidence in $w$ holds in $w^{\prime}$.

8 There is some controversy as to whether this is the right semantics for English must. Stone (1994) argues that the availability of evidence that decisively supports concluding $p$ is the essential feature that distinguishes sentences of the form must $p$ from plain $p$ (as well as from should $p$ ), not a set of assumptions of normalcy. von Fintel \& Gillies (2010) also highlight the evidential nature of must, but go one step further in claiming that must $p$ is not weaker than $p$, but entails $p$.

$9 f$ in (20) is a context-dependent choice-function that potentially narrows down the modal base B (which in their account is the set of accessible worlds, that is, $\bigcap f(w)$ in the system adopted in this paper)). Rullmann et al. (2008) use this function to account for the fact that modals in St'át'imcets do not lexically fix a quantificational force. 
Cuzco Quechua evidentials

b. Perceived-evidence inferential $\llbracket$-an' $\rrbracket^{c, w}$ is only defined if $c$ provides an epistemic modal base B s.t. for all worlds $w^{\prime}, w^{\prime} \in B(w)$ iff the perceived evidence in $w$ holds in $w^{\prime}$.

c. Reportative evidential $\llbracket \mathrm{ku} 7 \rrbracket^{c, w}$ is only defined if $c$ provides an epistemic modal base B s.t. for all worlds $w^{\prime}, w^{\prime} \in B(w)$ iff the relevant report made in $w$ is made in $w^{\prime}$.

d. $\llbracket \mathrm{k}^{\prime} \mathrm{a} \rrbracket^{c, w} / \llbracket-\mathrm{an}^{\prime} \rrbracket^{c, w} / \llbracket \mathrm{ku} 7 \rrbracket^{c, w}=\lambda f . \lambda p . \forall w^{\prime}\left[w^{\prime} \in f(B(w)) \rightarrow p\left(w^{\prime}\right)\right]$

In this type of account then, the only difference between epistemic modals and evidentials as well as between different types of evidentials is if and how their presuppositions constrain the modal base.

\section{Capturing the difference between inferential and non-inferential eviden- tials}

There are empirical differences between the four CQ evidentials (and between them and evidentials of other languages) that would not be captured if one simply adopted the existing evidentials-as-epistemic modals analyses. Firstly, with the two CQ inferentials, as well as with the epistemic modals in English, $p$ is presented as a conclusion following from the evidence, but this is not the case with the CQ Direct and Reportative. I propose that this can be captured by requiring a non-empty ordering source for the inferentials, while the Direct and Reportative do not make reference to an ordering source at all. Secondly, with the CQ Direct, but not the other evidentials, the speaker presents themselves as knowing that $p$. This is also partially accounted for by not involving an ordering source in the semantics of the Direct. Thirdly, with the CQ Reportative, the speaker may not believe $p$ or even believe $\neg p$. This can be captured by using a non-epistemic modal base in its semantics. These points will be addressed in more detail in the following sections.

First, however, I will briefly address the issue of whether the evidential meaning is a presupposition. The main motivation for analyzing evidential meaning as presuppositional is the fact that it can usually not be targeted by at-issue operators and therefore does not contribute to at-issue content. For example, negation cannot negate evidential meaning (see de Haan 1999 for cross-linguistic evidence, and Faller 2002 on CQ). The truth of the evidential claim cannot be directly challenged with That's not true etc. (Faller 2002), and instead requires a more indirect way such as Hey, wait a minute (von Fintel \& Gillies 2010). That is, it looks like evidential meaning projects like a presupposition. Most researchers acknowledge that evidential meaning is not presuppositional in the sense that it is taken for granted, however. That is, evidential meaning is usually new information. Without presenting a full argument here, there are also issues with determining what exactly it is that 
projects. For example, the 'presupposition' of a negated sentence with a Direct evidential is not I have direct evidence for $p$, as a standard presuppositional account would predict, but $I$ have direct evidence for $\neg p .{ }^{10}$ In Faller 2002, I analyzed the CQ evidentials as illocutionary modifiers, introducing a sincerity condition, e.g., $\operatorname{Direct}(p)$. The illocutionary analysis situates the evidential meaning also in a not-atissue dimension and moreover allows us to capture the intuition that the evidential claim is the main point of an evidential in a straightforward way. The analysis in the following sections will therefore take the evidential claim to be part of the truth conditions of the evidential sincerity conditions. The reader is asked to keep in mind, however, that while sincerity conditions have truth conditions of their own, they do not contribute to the truth conditions of the at-issue proposition $p$.

\subsection{Inference and the ordering source}

Recall that Rullmann et al. (2008) take the modal base of the General Inferential to contain those worlds in which the inferential evidence in the actual world holds (20a). However, it is not entirely clear what is meant by this. A proposition (or more precisely the event/fact described by the proposition) cannot be inferential evidence in general, it has to be inferential evidence for a particular proposition. For example, the fact that there is an empty wine bottle in John's room is inferential evidence for the proposition John drank the wine, but not for John ate a guinea pig, nor for There are empty wine bottles in John's room (cf. von Fintel \& Gillies 2010). In order to capture that a piece of evidence is only inferential evidence for a particular proposition, one could perhaps make the modal base a function not only on worlds but also propositions expressed. However, if we adopt a suggestion by Portner (2009), there is a simpler and more elegant way to capture the nature of inference. Note that the empty wine bottle in John's room is inferential evidence for John drank the wine only because it is a reasonable assumption that if there is an empty wine bottle in someone's room, then that person drank the wine. If we were to assume in addition that John only drinks wine when he eats a guinea pig, then the empty wine bottles would also constitute inferential evidence for John ate a guinea pig. Assumptions of this kind are, however, precisely what the ordering source is supposed to capture. Known facts such as There is an empty wine bottle in John's room become inferential evidence when they are taken in conjunction with less well-founded assumptions of normalcy or rules of thumb. One way of capturing the nature of inference is therefore to require that the ordering source be non-empty (Portner 2009: 171). There is then no need to specify the propositions in the modal

10 von Fintel \& Gillies (2010) solve this problem with English must by making its presupposition roughly speaker does not have direct evidence (or a trust-worthy report) for $p$ or $\neg p$, but it is not clear how the presupposition of a Direct could be reformulated to get the projection facts right. 
base as constituting inferential evidence. If a speaker has direct evidence for $p$, then the modal base directly supports $p$ and the ordering source is empty. Conversely, if the ordering source is not empty, then it follows that the modal base does not support $p$ directly.

There are of course also types of inference that do not involve normalcy assumptions or rules of thumb, for example, when $p$ is entailed by the propositions in the modal base. Such inferences can often be expressed using an inferential marker or by asserting $p$ directly. For example, the conclusion in (21) is expressed using must, but it would have been equally felicitous to conclude we can deduce that the answer is a positive number.

(21) We have a rule which states that the product of two negative numbers is a positive number. Thus, if we have the specific case of $(-3) \times(-4)$ we can deduce that the answer must be a positive number. (A General Rule which helps us to deduce a specific case.) (E-Z geometry.com) (Werner 2006)

While the use of must in such cases does not indicate that one of the premises is based on less than firm grounds, the speaker seems to leave open the possibility that they might have made a mistake in their deduction when using must. As Stone (1994) says, "the underlying motivations for using must reflect how the speaker takes into account his own capacity for ignorance, error and oversight [my emphasis] and the limited inferential resources of the addressee." In Kratzer's semantics we can capture this by assuming that the relevant ordering source in such cases is I have made no mistake. That is, the speaker sets aside those worlds in which mistakes are made in calculating the conclusion, but by indicating that they did so, they at the same time acknowledge that a mistake might nevertheless have occurred. The difference between must $p$ and plain $p$ in such cases is then that must emphasizes the inference process, which provides room for errors, while plain $p$ carries no surface signal of an inference having taken place, and leaves no room for error.

One further empirical piece of evidence suggesting that must points to the inference process is the fact that it is not (entirely) compatible with the speaker presenting themselves as knowing $p$ before making the inferential statement. ${ }^{11}$

11 Though there seem to be special contexts in which (22a) becomes acceptable. For example, it is improved if I know who ate the guinea pig is uttered with a special intonation that indicates that the speaker has just realized that $p$ is the case, possibly as a result of making the inference. Thanks to Bernadette Plunkett (p.c.) for pointing this out at SPINFest 2. Note also that must is compatible with the speaker coming to know $p$ as a result of an inference (von Fintel \& Gillies 2010). For example, in the situation described in (i), Chris knows that the ball is in the box; must indicates only that this knowledge was acquired via inference.

(i) Context: Chris' ball can only be in one of three boxes, A, B, C. She looks in A, it's not in there. She looks in B, it's not in there. She concludes: 
(22) a. I know who ate the guinea pig. ?? It must have been Juan.

b. I know who ate the guinea pig. It was Juan.

The fact that it is odd to assert knowing $p$ and then to indicate that one infers $p,(22 \mathrm{a})$, confirms that must indicates that the speaker has come to believe $p$ as a result of an inference process, which in the current analysis is captured by requiring a non-empty ordering source.

Some evidentials and epistemic modals can be used for pure speculation or for pointing out a logical possibility, neither of which involves the kind of inference process described above. Nevertheless, such elements can still be classed as indirect evidentials as they are infelicitous when the speaker has direct evidence for $p$ and because they point to a mental process as the source of information for $p$. The English modal verb may is arguably an evidential of this type (von Fintel \& Gillies 2010). Consider for example a situation in which I have no evidence or even a hunch as to whether it is raining right now in Nijmegen. In this context, (23a) is felicitous. But may can also be used in situations where there is some evidence in support of $p$. For example, I know from experience that it rains quite a lot in Nijmegen in October, and I might therefore issue the warning in (23b) to someone about to travel there.

a. It may or it may not be raining in Nijmegen right now.

b. Better take an umbrella. It might be raining in Nijmegen.

In the current framework, such evidentials can be distinguished from proper Inferentials by allowing but not requiring an ordering source. As will be discussed in the next two subsections, the two CQ Inferentials differ in what conditions they put on the ordering source. The Conjectural =chá allows the ordering source to be empty, whereas the PEI =chu-sina requires a non-empty ordering source.

\subsection{The Conjectural}

The CQ Conjectural usually indicates that the speaker has arrived at $p$ by reasoning from a set of facts, though it is silent on how these facts were acquired. If the premiss is made overt, as in (24) (repeated from (9a)), it may be marked by its own evidential.

(24) $M a n a=n$ para $k a n=c h u . ~ K u n a n$ wata=qa mana=chá allin=chu kuhichu

not $=\mathrm{BPG}$ rain be $=\mathrm{NEG}$ now year $=\mathrm{TOP}$ not $=\mathrm{CONJ}$ good $=\mathrm{NEG}$ harvest

ka-nqa!

be-3.FUT

'There is no rain. I guess/suppose/surely, the harvest this year will be bad!'

(ii) So, it must be in box C. 
Conjectural $=$ chá is also felicitous in situations where the speaker is merely speculating or pointing out a possibility. Thus, (25b) is fine in response to (25a) in a situation where B has no idea whether Inés will come or not.
a. A: Inés-cha=qa hamu-nqa?
Inés-DIM-TOP come-3.FUT
'Will Inés come?'
b. B: Ichapas=chá, mana-pas=chá.
maybe $=\mathrm{CONJ}$, not $=\mathrm{ADD}=\mathrm{CONJ}$
'Maybe, maybe not.'

Thus, the Conjectural is quite similar in meaning to English may, ${ }^{12}$ both in not requiring an ordering source and in being an existential quantifier. The main semantic difference with may is that it is not variable with respect to the kinds of conversational backgrounds it combines with, that is, =chá does not have deontic or bouletic uses, for example. In fact, none of the CQ evidentials is variable in this sense, and they all lexically fix the modal base and ordering source to a particular kind. For all but the Reportative (see section 5.2), the modal base is epistemic. I therefore analyze the CQ evidentials as asserting the existence of the relevant types conversational backgrounds instead of having the context provide them. Like Izvorski (1997), I assume that the ordering source of inferentials contains the speaker's beliefs regarding their evidence, that is, it is doxastic, $g_{d}(w)$. The semantics for the Conjectural is given in (26).

$$
\begin{aligned}
& \llbracket \operatorname{Conject}(p) \rrbracket^{w, c}=1 \text { iff there exists an epistemic modal base } f_{e} \text { and a doxastic } \\
& \text { ordering source } g_{d} \text { such that there exists some } w^{\prime} \in \max _{g_{d}}\left(\bigcap f_{e}(w)\right), \llbracket p \rrbracket^{w^{\prime}, c} \\
& =1 \text {. }
\end{aligned}
$$

The output of the ordering source for a particular world $w$ may be empty, that is, the speaker may not hold any relevant beliefs, thus accounting for examples like (25). If it is not empty, that is, if the speaker relies on further assumptions, we get a more properly inferential use of the Conjectural, such as (24). In this example, the modal base contains the fact that there is no rain, and the ordering source the assumption that the harvest will be bad if there is no rain, which may be based on prior experience or general knowledge.

Given that no requirements are imposed the ordering source, the Conjectural is a rather weak evidential. It is an evidential only by virtue of pointing to a mental process as source of information, which, when the ordering source is empty, amounts to nothing more than quantification over possible worlds that are compatible with what is known in the actual world.

12 Though $=$ chá is quite different from may in other respects, e.g., it cannot embed or otherwise be in the scope of at-issue operators, whereas may can. 


\subsection{Inference from perceived evidence}

Turning now to $=$ chu-sina, as mentioned in section 2 , this evidential requires the inference to be based on perceived evidence, often the result of the event described. That is, this evidential imposes a restriction on how (some of) the premises in the modal base were acquired. (27) (repeated from (10)) illustrates this use.

$$
\begin{aligned}
& \text { Unqu-sqa=chu-sina ka-sha-n-man. } \\
& \text { sick-PRT=PEI } \quad \text { be-PROG-3-COND. }
\end{aligned}
$$

'She appears to be sick.'

It is unclear at the moment whether it is possible for the speaker to entertain both $p$ and $\neg p$ using =chu-sina as is the case with =chá, (25), and data from native speakers still needs to be collected. However, a non-native but fluent speaker of Cuzco Quechua gives the judgments indicated in (28).

$$
\begin{aligned}
& \text { a. Unqu-sqa=chu-sina ka-sha-n-man. Mana-pas=chá. } \\
& \text { sick-PRT=PEI be-PROG-3-COND not-ADD=PEI/=CHÁ. } \\
& \text { 'She appears to be sick. (But) maybe she isn't.' } \\
& \text { b. Unqu-sqa=chu-sina ka-sha-n-man. \#Mana-pas=chu-sina. } \\
& \text { sick-PRT=PEI be-PROG-3-COND not-ADD=PEI/=CHÁ. }
\end{aligned}
$$

The possibility of (28a) suggests that a speaker using =chu-sina indicates that they have evidence in support of $p$, but that this evidence is not strong enough to eliminate the possibility of $\neg p$. However, the speaker cannot claim that the available evidence supports $p$ as well as $\neg p$. That is, the speaker is not merely raising $p$ as a possibility, but reasoning from the available evidence, which can be captured in the type of account developed here by requiring a non-empty ordering source. Since $\neg p$ is not completely ruled out, as evidenced by (28a), the quantificational force is existential.

PEI $=c h u$-sina thus requires a modal base $f_{p e}$ that contains propositions describing events perceived by the speaker, and a non-empty doxastic ordering source that contains assumptions that links these events to likely causes. The semantics for =chu-sina can be given as in (29b).

a. Perceptual modal base: $f_{p e}(w)=\{p \mid s$ perceived/-s the event described by $p$ in $w\}$

b. $\llbracket P E I(p) \rrbracket^{w, c}=1$ iff there exists a non-empty perceptual modal base $f_{p e}(w) \subseteq f_{e}$ and a non-empty doxastic ordering source $g_{d}(w)$ s.t. there is some $w^{\prime} \in \max _{g_{d}}\left(\bigcap f_{p e}(w)\right), \llbracket p \rrbracket^{w^{\prime}, c}=1$. 
Cuzco Quechua evidentials

Applying this to example (27), the modal base contains the fact that she is pale, and the ordering source the assumption that if people are pale then they are sick.

To summarize, this section has shown that the doubly-relative semantics developed by Kratzer to account for modality can fruitfully be applied to inferential evidentials in CQ. Inferentials are evidentials by virtue of referring to a mental reasoning process as the speaker's source of information. This condition is met by English may and the CQ Conjectural =chá even when these are used only to point out a logical possibility. We get a stronger sense of an inference being performed when these elements are used in conjunction with an ordering source. The PEI $=$ chu-sina is more obviously an inferential in that it specifies that a process of inference has taken place involving premises in addition to what is perceived and known. It is also an evidential proper in the sense that it tells us how the propositions in the modal base were acquired. The two non-inferential evidentials of CQ can also be analyzed as imposing restrictions on the modal base, as discussed in the next section.

\section{Non-Inferential evidentials as restrictors of the modal base}

Neither the Direct or the Reportative in CQ present $p$ as a conclusion following from a set of premises, there is no overt indication that speaker has performed an inference. Since I have suggested in the previous section that the use of an ordering source indicates an inference, the semantics for these two evidentials should not include one. Their main evidential contribution is captured as a restriction on the propositions in the modal base.

\subsection{Direct}

Consider an example like (30) (repeated from (6)). (30) asserts $p$ as a fact and at the same time conveys that the speaker has direct evidence for it. Upon hearing (30), the hearer can assume that the speaker has seen first hand that 'he' is living with her niece.

Subrina-y-wan=mi tiya-sha-n.

niece-1-COM=BPG live-PROG-3

'He is living with my niece.'

EV: $s$ has seen that he is living with her niece.

(conversation)

Unlike the CQ Inferentials, the CQ Direct has very little in common with typical epistemic modals. Sentences containing $=m i$ assert that $p$ is true, not that $p$ is necessarily or possibly true, that is, they entail $p$. Moreover, they are compatible with the speaker presenting themselves as knowing $p$, while epistemic modals are not (see, e.g., (22)). Thus, (31) is fine. 
Yacha-ni pi-n mikhu-rqa-n quwi-ta chay-ta. Juan=mi. know-1 who-BPG eat-PST-3 guinea.pig-ACC this-ACC Juan=BPG

'I know who ate the guinea pigs. It was Juan.'

EV: $s$ saw that Juan ate the guinea pig.

This is unsurprising, given that perceptions are usually considered our most direct link with states of affairs in the world. We take our perceptions to be knowledge (Dancy 1985: 178), and propositions acquired via perception can directly be stated as fact. Why would one then want to consider an analysis of direct evidentials as quantifiers over epistemically accessible possible worlds? There are two reasons. One, direct evidentials are epistemic in the sense that they tell us something about the speaker's epistemic state and not directly about how the world is. While perceptions are our most direct access to the world, they can be mistaken. Imagine, for example, an optical illusion in which two lines appear not to be parallel when in fact they are. A speaker who is not aware of the illusion can legitimately assert that the two lines are not parallel using the direct evidential, because that is what they see. Similarly for hallucinations and other perceptual errors. However, once they have been made aware of the illusion, the Direct is no longer felicitous, even if the speaker still sees two non-parallel lines. A second reason to consider an epistemic analysis for the CQ direct evidential is the fact that it actually allows for a minimal amount of reasoning from the perceived evidence to $p$. However, this reasoning is very restricted and must not involve any stereotypical or otherwise weak assumptions. The type of inference permissible with $=m i$ is illustrated in (32).

a. Context: $s$ has direct evidence that Marya bought two guinea pigs from Inés and that she also bought three guinea pigs from Gloria in a separate event.

b. Pisqa quwi-ta $=\mathbf{n} \quad$ ranti-rqa-n.

five guinea.pig-ACC $=$ BPG buy-PST-3

'She bought five guinea pigs.'

EV: $s$ saw that she bought five guinea pigs.

That is, =mi can be used for asserting an immediate entailment of the speaker's direct evidence. By "immediate" entailment I mean an entailment that is immediately obvious to the speaker without them having to perform conscious calculations or deductions. What is an immediate entailment is context and speaker dependent. A school child who has just learnt the basics of arithmetics would probably not be in a position to assert (32). Just like non-modalized sentences in English, which can also be used to convey such "inferences", CQ sentences with =mi do not admit the possibility that the speaker might have made a mistake in their deduction (see 
discussion of (21)). Indeed, such sentences are used to convey knowledge. They do not convey that any kind of inference was involved. That is, from hearing (32), the hearer would have no idea whether Marya bought five guinea pigs in one transaction or in two or more transactions. Thus, while $=m i$ is compatible with this type of minimal inference, it is not an inferential. ${ }^{13}$

I am aware of only one suggestion in the literature of analyzing direct, more specifically visual evidentiality using Kratzer's framework of modality, namely Lecarme 2008. Lecarme suggests that visual evidentiality involves an epistemic modal base and a perceptual ordering source, with the latter ordering the epistemically accessible worlds in such a way that "in the most ideal or 'normal' of her worlds, the speaker has DIRECT (visual) evidence" (Lecarme 2008: 218). However, the introduction of an ordering source results in $p$ not being entailed by a sentence with a visual evidential, as the actual world might be amongst those eliminated by it from the modal base. CQ sentences with the Direct $=m i$, however, entail $p$ and that the speaker has direct evidence in the actual world. I therefore analyze this evidential as restricting the modal base. In particular, I propose that it, like the PEI $=c h u$-sina, requires a non-empty perceptual modal base $f_{p e}(w)$, that is, a modal base that contains propositions describing the speaker's perceptions. In contrast to $=c h u$-sina , however, the Direct $=m i$ makes no reference to an ordering source. ${ }^{14}$ The semantics for Direct $=m i$ is then (33). ${ }^{15}$

13 The notion of "immediate entailment" requires a formal definition and probably a better name, but I will leave it for the time being as the intuitive notion as explained in the text. Note that "immediate entailment" is not quite the same as von Fintel \& Gillies's (2010) notion of a modal base directly settling the question of $p$, which they use to account for the indirectness requirement of epistemic must and other modals. One way to define direct settledness is as in (i).

(i) A modal base $f(w)$ directly settles whether $p$ iff either there is a proposition in $f(w)$ that entails $p$ or there is a proposition in $f(w)$ that contradicts $p$.

Since direct settlement crucially relies on $p$ being entailed or contradicted by a single, independent proposition in the modal base, not, for example, by a conjunction of several propositions, this will not work for the CQ Direct $=m i$. As we have seen in example (32), this evidential allows $p$ to be entailed by a conjunction of independent propositions in the perceptual modal base.

14 This in and of itself might be enough to capture the notion of an immediate entailment. As suggested above, the ordering source can not only be used to indicate that the speaker is reasoning from less than firm premises, but also to indicate that there is a possibility of a mistake having occurred during the inference process. Thus, only people for whom an entailment is immediately obvious will not hedge their conclusion by indicating such an ordering source. Further fieldwork will be needed to determine whether an expert can use $=m i$ to state conclusions that are not obvious to other people using $=m i$. If so, this would support the analysis proposed here.

15 This semantics is very similar to Hintikka's (1969) semantics for perception reports in (i).

(i) $a$ perceives that $p=$ in all possible states of affairs compatible with what $a$ perceives it is the case that $p$. (Hintikka 1969: 155) 
$\llbracket \operatorname{Direct}(p) \rrbracket^{w, c}=1$ iff there exists a non-empty perceptual modal base $f_{p e}(w) \subseteq f_{e}$ s.t. for all $w^{\prime} \in \bigcap f_{p e}(w), \llbracket p \rrbracket^{w^{\prime}, c}=1$.

Note that because we take our direct perceptions to constitute knowledge, a perceptual modal base is a subset of an epistemic modal base, as I have already assumed, but not commented on in (29).

\subsection{Reportative}

The Reportative $=s i$ is also not immediately obviously a quantifier over possible worlds. Sentences containing it do not convey necessarily or possibly $p$ but simply $p$, and there is no indication of the speaker having performed an inference. Thus, (34) (repeated from (8c)) says that someone told the speaker that some hit and kicked "him", not that this follows from what they were told.

Wakin=si maqa-mu-n-ku hayt'a-mu-n-ku. some $=$ REP hit-CIS-3-PL kick-CIS-3-PL

'Some hit and kicked (him).'

EV: $s$ was told that some hit and kicked him.

Nevertheless, as with the Direct, the Reportative allows $p$ to be the result of a minimal amount of inference, and this again justifies a modal analysis of $=s i$. For example, in a context where I was told that Inés will go to Lima on Sunday and asked whether she'll be at a meeting in Cuzco on Sunday, I can say (35), which is an inference based on the premiss that if a person is in Lima they cannot be in Cuzco.

$$
\begin{aligned}
& \text { Mana=s kay-pi=chu ka-nqa. } \\
& \text { not=REP here-LOC=NEG be-3.FUT }
\end{aligned}
$$

'She won't be here.'

EV: $s$ was told that she won't be here.

Only immediate inferences of this kind are allowed with the Reportative.

Previous analyses of reportative evidentials differ in how the modal base is defined, thereby capturing an empirical difference between types of reportatives. With some reportatives, the fact that someone said $p$ is taken as evidence for $p$, whereas others only convey that someone said $p$ without that necessarily being taken to provide support for the truth of $p$. The difference can be illustrated with reportative adverbials in English. Compare (36a) with (36b) (Kratzer 2010).

Direct $=m i$ differs from perception verbs in allowing a wider range of direct evidence, as discussed in section 2, and in not contributing to the at-issue content (Faller 2002), but otherwise, it seems appropriate to give it a similar semantics to perception verbs. 
Cuzco Quechua evidentials

(36) a. Given the rumour, Roger must have been elected chief (\#but I wouldn't be surprised if he wasn't.)

b. According to the rumour, Roger must have been elected chief (but I wouldn't be surprised if he wasn't.)

(36a) is true if the speaker considers the rumour to be reliable evidence on the basis of which it can be concluded that Roger was elected chief. Hence it cannot be continued with a statement that leaves open the possibility that $p$ is false. In contrast, (36b) is true if the rumour said that Roger was elected chief, regardless of whether that is actually true or not.

The CQ Reportative $=s i$ is compatible with the speaker knowing/believing $p$ as well as with the speaker knowing/believing $\neg p$, or not having any opinion on the truth of $p$ at all. (37) illustrates the case where the speaker knows $p$ to be false.

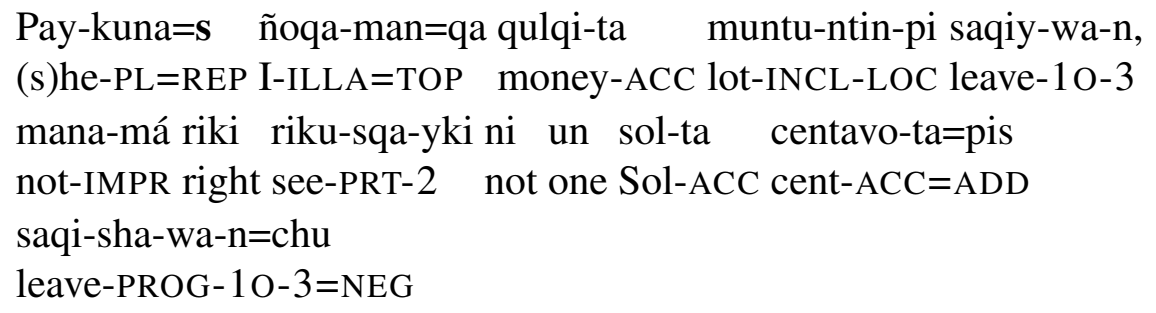

'They left me a lot of money, (but) that's not true, as you have seen, they didn't leave me one sol, not one cent.'

The speaker of (37) first says using the Reportative that "they" left her a lot of money, but then goes on to say that this is not true. Thus, the CQ Reportative patterns with according to. However, the St'át'imcets Reportative can only be used if the speaker believes $p$ to be at least possible (Matthewson et al. 2007), and therefore patterns with given that. Recall Rullmann et al.'s (2008) definition of the presupposed modal base for the St'átimcets Reportative $k u 7$ in (38a) and its assertion in (38b) (repeated from (20)).

a. $\llbracket \mathrm{ku} 7 \rrbracket^{c, w}$ is only defined if $c$ provides an epistemic modal base B such that for all worlds $w^{\prime}$, $w^{\prime} \in B(w)$ iff the relevant report made in $w$ is made in $w^{\prime}$.

b. $\llbracket \mathrm{ku} 7 \rrbracket^{c, w}=\lambda f . \lambda p . \forall w^{\prime}\left[w^{\prime} \in f(B(w)) \rightarrow p\left(w^{\prime}\right)\right]$

The modal base contains worlds in which the relevant report is made, and because it is an epistemic modal base, in which the speaker's beliefs are true. Thus, a reportative statement with $k u 7$ will be true only if the reported proposition is compatible with what the speaker believes. Moreover, since the actual world is one of the accessible worlds, $p$ is claimed to be true in the actual world. This way of constructing the modal base will not suit the CQ Reportative. 
A second way of constructing the modal base is to include the contents of the relevant reports. This was, for example, proposed by Ehrich (2001) for the reportative uses of the German modal verb sollen. ${ }^{16}$ In recent work, Kratzer (2010) has called such conversational backgrounds informational, as they represent the information conveyed by reports and other sources of information.

Let us define an informational reportative background $f_{r}(w)$ as a function from worlds to propositions that represent the content of what is said, as in (39).

$$
f_{r}(w)=\{p \mid p \text { is the content of what is said in } w\}
$$

With this type of modal base, the semantics of CQ Reportative can be defined as in (40). As mentioned above, the CQ Reportative does not indicate that the speaker is making an inference, that is, on the analysis proposed here, there is no ordering source involved.

$\llbracket \operatorname{Report}(p) \rrbracket^{w, c}=1$ iff there exists a non-empty reportative informational modal base $f_{r}(w)$ s.t. for all $w^{\prime} \in \bigcap f_{r}(w), \llbracket p \rrbracket^{w^{\prime}, c}=1$

The modal base here does not necessarily include the actual world, because a report that $p$ might have been made in the actual world without $p$ being true. That is, this analysis correctly captures the fact that with the CQ Reportative, the speaker is not committed to any degree to $p$, and indeed, may believe that $p$ is false. Such a modal base is then not epistemic, as it does not have to be compatible with the speaker's beliefs.

\section{Conclusion}

This paper has developed an analysis of the CQ evidential enclitics using Kratzer's framework of double-relative modality. The different types of conversational backgrounds offered by this framework have proven very useful in capturing the differences between the individual evidentials. One major distinction can be drawn between inferential and non-inferential evidentials. The proposal put forward here is that Inferentials rely on an ordering source, whereas non-inferential evidentials do not make reference to this type of conversational background. This distinction captures the empirical observation that Inferentials point to a conscious inferential process on part of the speaker as the source of information, which may be based on possibly non-factual assumptions and which may have the potential to be faulty in some way. In contrast, non-inferential evidentials, while compatible with a restricted

16 Ehrich (2001: 168) characterizes the accessible worlds for reportative sollen as those that specify the statements of X ("die die Behauptungen von X [spezifizieren]"), where X is a particular, possibly unspecified, source. 
type of inference, do not indicate that such an inference is involved. Instead, they point to the way the propositions in the modal base were acquired. As we have seen the PEI =chu-sina has elements of both: it restricts the propositions in the modal base to those that were perceptually acquired and indicates the embedded proposition is the result of an inference.

Turning now to the question of whether evidentials can be subsumed under the category of epistemic modals, my answer would be 'no'. If we assume that an epistemic element is one that makes reference to an individual's or group's knowledge, here captured as an epistemic modal base, then the Reportative is clearly not an epistemic element. In contrast, the Inferentials and the Direct $=m i$ are. Now, I am somewhat hesitant to call Direct $=m i$ an epistemic modal, though it is clearly an epistemic operator, as it does not express necessity in the same way as must does, for example. In the same vein, I would hesitate to call verbs of knowledge or perception epistemic modals. However, my hesitation here might simply be a consequence of the fact that it is usually inferentials that are discussed as the prime examples of epistemic modals. Thus, if we define an epistemic modal as a quantifier over epistemically accessible worlds, then the Direct $=m i$, along with verbs of knowledge and perception, is also an epistemic modal. Are epistemic modals a subclass of evidentials? In section 4.1, I said that epistemic modals like must and may are evidentials by virtue of not being compatible with the speaker having direct evidence for $p$ and by pointing to a mental process as the source of information. However, if we include verbs of knowledge and expressions of degree of certainty such as perhaps or certainly in the category of epistemic modals, then we have examples of epistemic modals that are not evidentials, as these do not give any indication about what type of evidence the speaker has for $p$. Thus, with a definition of epistemic modals as quantifiers over epistemically accessible worlds, the categories of evidentials and epistemic modals are distinct but overlapping categories.

\section{References}

Aikhenvald, Alexandra Y. \& R. M. W. Dixon (eds.). 2003. Studies in evidentiality. Oxford: John Benjamins Publishing Company.

Cusihuaman, Antonio. 2001. Gramática Quechua: Cuzco-Collao. Cuzco: Centro de Estudios Regionales Andinos "Bartolomé de las Casas" 2nd edn.

Dancy, Jonathan. 1985. An introduction to contemporary epistemology. Oxford: Blackwell.

Ehrich, Veronika. 2001. Was nicht müssen und nicht können (nicht) bedeuten können: Zum Skopus der Negation bei den Modalverben des Deutschen. In Reimar Müller \& Marga Reis (eds.), Modalität und Modalverben im Deutschen, vol. 9 Linguistische Berichte Sonderhefte, 149-176. Hamburg: Buske. 
Faller, Martina. 2002. Semantics and pragmatics of evidentials in Cuzco Quechua: Stanford University dissertation.

Faller, Martina. 2004. The deictic core of "non-experienced past" in Cuzco Quechua. Journal of Semantics 21(1). 45-85. doi:10.1093/jos/21.1.45.

von Fintel, Kai \& Anthony S. Gillies. 2010. Must ... stay ... strong! Natural Language Semantics doi:10.1007/s11050-010-9058-2. Online First.

von Fintel, Kai \& Sabine Iatridou. 2005. What to do if you want to go to Harlem: Anankastic conditionals and related matters. Draft of a paper for the Rutgers Semantics Workshop.

de Haan, Ferdinand. 1999. Evidentiality and epistemic modality: Setting boundaries. Southwest Journal of Linguistics 18(1). 83-101.

Hintikka, Jaakko. 1969. On the logic of perception. In Jaakko Hintikka (ed.), Models for modalities. selected essays, 151-183. Dordrecht: D. Reidel.

Itier, César (ed.). 1999. Karu Nankunapi. Cuzco: Centro de Estudios Regionales Andinos "Bartolomé de Las Casas".

Izvorski, Roumyana. 1997. The present perfect as an epistemic modal. In A. Lawson \& E. Cho (eds.), SALT VII, Cornell: CLC Publications.

Kratzer, Angelika. 1981. The notional category of modality. In H.-J. Eikmeyer \& Hannes Rieser (eds.), Words, worlds, and contexts: New approaches in word semantics, 38-74. Berlin: de Gruyter.

Kratzer, Angelika. 1987. Modality. In Arnim von Stechow \& Dieter Wunderlich (eds.), Handbook of semantics, 639-650. Berlin: Walter de Gruyter.

Kratzer, Angelika. 2010. Collected papers on modals and conditionals, chapter 2. To be published by OUP, available at: semanticsarchive.net.

Lecarme, Jacqueline. 2008. Tense and modality in nominals. In J. Guéron \& J. Lecarme (eds.), Time and modality, vol. 75 Studies in Natural Language and Linguistic Theory, 195-226. Berlin: Springer.

Matthewson, Lisa. 2010. Evidence about evidentials: Where fieldwork meets theory. Handout of talk at Linguistic Evidence 2010, Eberhard Karls Universität Tübingen.

Matthewson, Lisa, Henry Davis \& Hotze Rullmann. 2007. Evidentials as epistemic modals: evidence from St'át'imcets. Linguistic Variation Yearbook 7. 201-254.

Murray, Sarah. 2009. A Hamblin semantics for evidentials. In Satoshi Ito \& Ed Cormany (eds.), SALT XIX, Cornell: CLC Publications.

Portner, Paul H. 2009. Modality. Oxford: Oxford University Press.

Rullmann, Hotze, Lisa Matthewson, \& Henry Davis. 2008. Modals as distributive indefinites. Natural Language Semantics 16. 317-357. doi:10.1007/s11050-0089036-0.

Schenner, Mathias. 2008. Double face evidentials in German: Reportative 'sollen' and 'wollen' in embedded contexts. In Atle Grønn (ed.), Proceedings of Sinn 
Cuzco Quechua evidentials

und Bedeutung 12, 552-566. Oslo: University of Oslo.

Stone, Matthew. 1994. The reference argument of epistemic must. In Proceedings of IWCS 1, 181-190.

Werner, Tom. 2006. Future and non-future modal sentences. Natural Language Semantics 14(3). 235-255. doi:10.1007/s11050-006-9001-8.

Willett, Thomas. 1988. A cross-linguistic survey of the grammaticization of evidentiality. Studies in Language 12(1). 51-97. doi:10.1075/sl.12.1.04wil.

Martina Faller

School of Languages, Linguistics and Cultures

The University of Manchester

Manchester M13 9PL

United Kingdom

m.faller@manchester.ac.uk 